\title{
Dialectal influence on chronic pulmonary disease assessment test: the reliability and validity study
}

\author{
This article was published in the following Dove Press journal: \\ International Journal of COPD \\ II March 2015 \\ Number of times this article has been viewed
}

\author{
Chaicharn Pothirat \\ Warawut Chaiwong \\ Nittaya Phetsuk \\ Chalerm Liwsrisakun \\ Chaiwat Bumroongkit \\ Athavudh Deesomchok \\ Theerakorn Theerakittikul \\ Atikun Limsukon \\ Division of Pulmonary, Critical Care \\ and Allergy, Department of Internal \\ Medicine, Faculty of Medicine, Chiang \\ Mai University, Chiang Mai, Thailand
}

Correspondence: Chaicharn Pothirat Division of Pulmonary, Critical Care and Allergy, Department of Internal Medicine, Faculty of Medicine, Chiang Mai University, I 10 Inthavaroros Road, Sriphum, Maung Chiang Mai District, Chiang Mai 50200, Thailand

Tel +6653946228

Fax +66 $53895 \quad 117$

Email cpothira@med.cmu.ac.th; chaicharn.p@cmu.ac.th
Background: Chronic obstructive pulmonary disease (COPD) patients living in many countries are familiar with local dialects rather than the official language. We, therefore, compare the reliability and validity of the COPD Assessment Test (CAT) in Thai and northern Thai dialect versions, in stable COPD patients living in the northern part of Thailand.

Methods: A total of 160 COPD patients were randomly selected for the evaluation of each dialect version of CAT $(n=80)$. The internal consistency of all eight items and test-retest reliability were investigated by using Cronbach's alpha coefficient and intraclass correlation coefficient (ICCC), respectively. The validity was evaluated by the degree of correlation with St George's Respiratory Questionnaire (SGRQ) using Pearson's correlation. The correlations of CAT with clinical parameters such as forced expiratory volume in the first second $\left(\mathrm{FEV}_{1}\right)$, modified Medical Research Council scale (mMRC) dyspnea score, and 6-minute walk distance (6-MWD) were also evaluated.

Results: The two versions of CAT showed high internal consistency reliability (Cronbach's alpha coefficient of 0.82 and 0.76 ) as well as a high test-retest reliability (ICCC of 0.82 and 0.84 ) for Thai and northern Thai dialect versions, respectively. The test results revealed that the northern Thai dialect version had good correlation with SGRQ whereas the Thai version correlated only moderately.

Conclusion: The two Thai versions of CAT were proven to be good clinical tools with high reliability and acceptable validity for assessing the quality of life of Thai COPD patients. However, the northern Thai dialect version is more suitable for evaluating COPD patients living in the northern part of Thailand.

Keywords: chronic obstructive pulmonary disease, COPD assessment test, quality of life, validation, reliability

\section{Introduction}

Chronic obstructive pulmonary disease (COPD), an important cause of morbidity and mortality worldwide, is characterized by progressive airflow limitation that is partially reversible. ${ }^{1}$ The Global Burden of Disease Studies found that COPD was the sixth commonest cause of death worldwide in 1990 but made the alarming prediction that it could become the third commonest cause of death by 2020 irrespective of public health intervention. Furthermore, COPD was recognized as being the 12 th greatest cause of chronic morbidity, with a predicted increase to become the fourth most important disability-producing illness by $2020 .^{2-4}$ The assessment of health status has become an increasingly important outcome measure for COPD. This includes collecting information on daily symptoms, activity limitation, and other manifestations of the disease. Routine clinical evaluations and a critical step in management are to obtain reliable and valid information on the impact of the disease on their health status obtained from the patients themselves. Health status measurements such as that provided by 
St George's Respiratory Questionnaire (SGRQ) and the Chronic Respiratory Questionnaire (CRQ) have provided well-validated measurements of disability and handicap due to COPD, but these are complex to administer and score in routine clinical practice. ${ }^{5,6}$ The COPD Assessment Test (CAT) with a target number of eight items was proven to have good measurement properties and validity for several English speaking countries. ${ }^{7}$ CAT was easy to complete, interpret, and could be readily incorporated into routine care for quality-of-life evaluation of COPD patients. The eight items included in the test are cough, phlegm, chest tightness, breathlessness, activity limitation, confidence, sleep, and energy. They were divided into three domains: symptoms (cough, phlegm, chest tightness), physical activities (breathlessness, activity limitation), and impacts (confidence, sleep, energy). Items were formatted as a semantic differential 6-point scale and defined by contrasting adjectives. ${ }^{7}$ The range of CAT score is 0-40. Similar to other countries in the world, several regional dialects are used for communication in different regions of Thailand. Health literacy issues and ineffective communication place patients at risks for misunderstandings. Cultural, language, and communication barriers - singly or in combination - can give rise to mutual misinterpretation between patients and health care providers. Therefore, the clarity of communication becomes important in light of interpretation and evaluation. Most COPD patients living in northern Thailand are elderly people who are more familiar with the northern Thai dialect than Thai language and use the former in their daily communication. Based on this fact, we initiated this study to determine the more appropriate versions to build the CAT questionnaire that could be applied to COPD patients living in the northern part of Thailand.

\section{Materials and methods}

The study was conducted as a cross-sectional validation design with two visits. All subjects were recruited from the outpatient chest clinic of Chiang Mai University Hospital, Chiang Mai, Thailand between October 2010 and December 2010. This study was approved by the Research Ethics Committee, Faculty of Medicine, Chiang Mai University, and written informed consents were obtained from all patients. The inclusion criteria were COPD patients with post-bronchodilator ratio of forced expiratory volume in the first second $\left(\mathrm{FEV}_{1}\right)$ to force vital capacity (FVC) $(<0.7$ in accordance with the Global Initiative for Chronic Obstructive Lung Disease (GOLD), ${ }^{8}$ smokers or ex-smokers with a smoking history $>10$-pack years, age $>40$ years, onset of symptoms $>40$ years, and without a history of acute exacerbation for at least 3 months prior to enrollment. The exclusion criteria were a past history of asthma, family history of asthma, disability due to coexisting pulmonary or non-pulmonary diseases, and being incapable of understanding the questionnaire.

\section{Study procedures}

The linguistic validation process in accordance with cultural adaptation involved forward translation of the original English CAT to Thai (Table S1) and northern Thai dialect (Table S2) versions by the study team and backward translation into English by two native English speakers. One could read and understand Thai language whereas the other could speak and understand northern Thai dialect well. The process also included two reviewers to verify the appropriate translation of medical terms as well as a pilot test performed in ten patients with COPD. Both translations had been tested with northern Thai patients in Chiang Mai.

To evaluate both versions of CAT, we examined their reliability (internal consistency and reproducibility) in subjects with COPD living in the northern part of Thailand, and then tested the validity of the versions by their correlations with SGRQ. ${ }^{9}$ The correlations with modified Medical Research Council scale (mMRC), ${ }^{10} \mathrm{FEV}_{1}$, and 6-minute walk distance (6-MWD) were also assessed. Patients were randomized to fill one of the two CAT versions (Thai or northern Thai dialect versions), at baseline and between 4 and 12 weeks, to assess reproducibility (test-retest) using the same version of questionnaire. The subjects were assessed for post-bronchodilator pulmonary function using a standard spirometer (Spirolab II and reference values for Knudson $1983)^{11}$ at baseline visit. On the same day, the patients performed a 6-minute walk test (6-MWT) in accordance with the American Thoracic Society criteria, ${ }^{12}$ after which CAT, SGRQ, and mMRC were administered.

\section{Statistical analysis}

The reliability and validity of the two CAT versions were evaluated in this study. The former was estimated by measuring the internal consistency and test-retest reliability of the questionnaires. Internal consistency measured the degree of association between the questionnaire items whereas test-retest reliability measured the ability of the questionnaire to produce consistent scores over a short period in stable subjects. The internal consistency of the 8 -item questionnaire was measured by applying Cronbach's alpha coefficient to CAT scores, with values $>0.7$ considered acceptable for aggregate data. ${ }^{13}$ The reproducibility 
(test-retest reliability) of the questionnaire was estimated by calculating the intraclass correlation coefficient (ICCC) for CAT between two stable visits. The validation process involved comparing these with SGRQ using Pearson's correlation. The correlations between CAT scores with the other clinical parameters $\left(\mathrm{mMRC}, \mathrm{FEV}_{1}\right.$, and 6-MWD) were also analyzed by the same method. We used the following cut-offs: $0<|r|<0.3$, weak correlation; $0.3<|r|<0.7$, moderate correlation; and $|r|>0.7$, strong correlation. ${ }^{14}$ Student's $t$-test was used to compare the groups. Differences in proportions were analyzed using $\chi^{2}$ tests. Statistical significance was accepted at $P<0.05$ and summary results were presented as mean \pm SD or N (\%). All analyses were carried out with the SPSS statistical package, version 16 for Windows.

\section{Results}

In this study, a total of 180 subjects diagnosed with COPD from the outpatient chest clinic of Chiang Mai University Hospital were assessed for eligibility during October 2010 to December 2010. One hundred and sixty stable COPD patients were determined to meet the inclusion criteria and were randomized to each version of the CAT questionnaire (Figure 1). There were no significant differences of baseline characteristics among the two groups in terms of sex, age, body mass index (BMI), lung function, quality of life, dyspnea severity, CAT score, exercise capacity, GOLD stage of the disease, and inhaled medication used (Table 1).

\section{Test of reliability}

The internal consistency of CAT showed a high internal consistency with Cronbach's alpha coefficient of 0.83 for Thai and 0.78 for northern Thai dialect versions. The test-retest reliability in COPD patients of both versions of the questionnaire was equally good at ICCC 0.82 and 0.84 for Thai and northern Thai dialect versions, respectively.

\section{Test of validity}

The Thai version showed moderate correlation whereas the northern Thai dialect version showed strong correlation with SGRQ ( $r=0.60$ and $0.77, P<0.001$, respectively; Figure 2A and $\mathrm{B})$. Each domain of CAT showed significant correlations with those of SGRQ (Table 2). Symptom domain correlations were moderate for both versions $(r=0.57$ and 0.55 ,

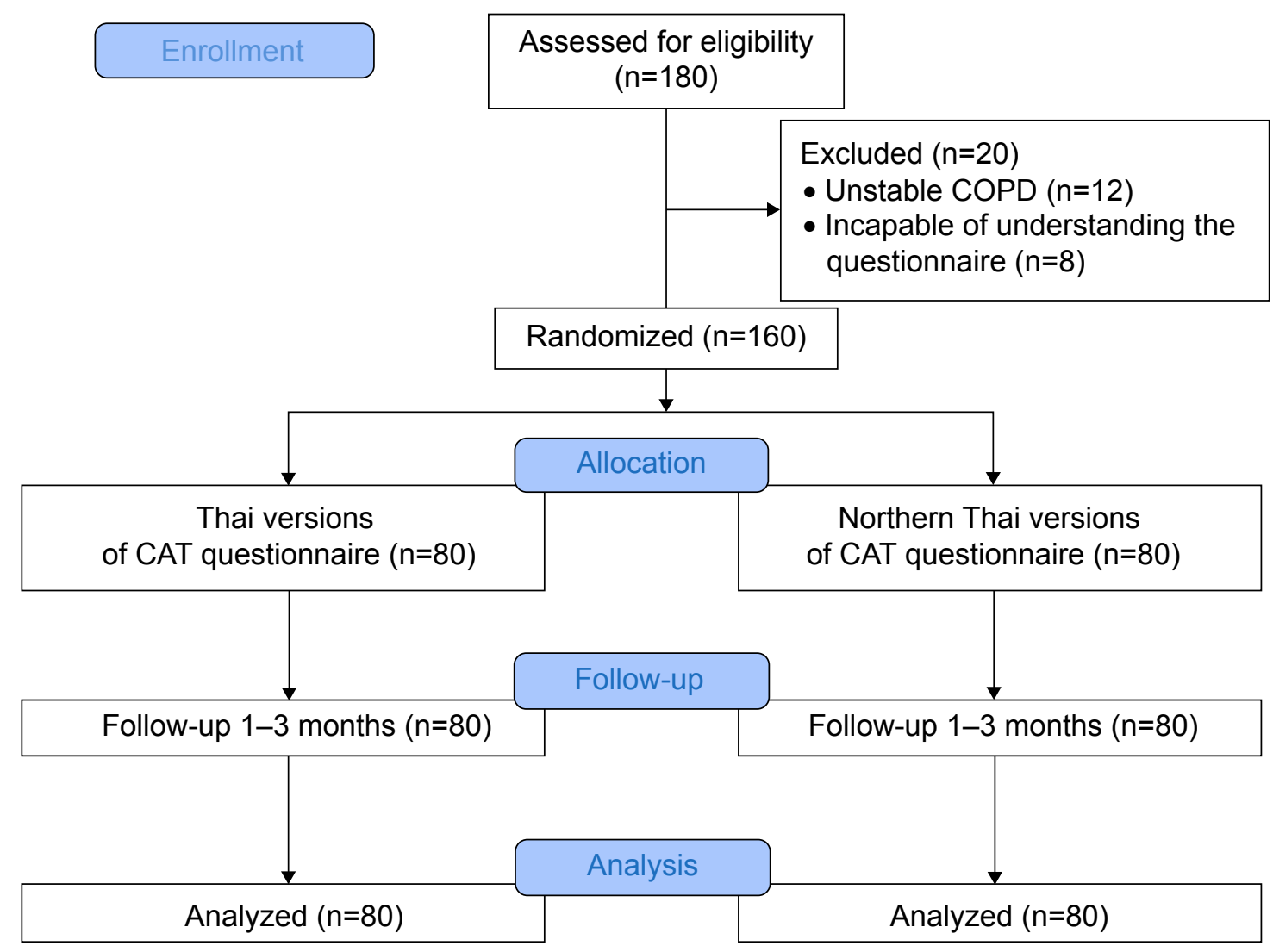

Figure I Schematic diagram of randomization.

Abbreviations: COPD, chronic obstructive pulmonary disease; CAT, COPD Assessment Test. 
Table I Characteristics of 160 patients with COPD enrolled in the study

\begin{tabular}{|c|c|c|c|}
\hline Variables & $\begin{array}{l}\text { Thai version } \\
(\mathbf{N}=\mathbf{8 0})\end{array}$ & $\begin{array}{l}\text { Northern Thai } \\
\text { dialect version } \\
(\mathbf{N}=\mathbf{8 0})\end{array}$ & $P$-value \\
\hline $\operatorname{Sex}(M: F) \%$ & $60.0: 40.0$ & $55.0: 45.0$ & 0.52 \\
\hline Age (year) & $72.3 \pm 8.7$ & $70.7 \pm 9.2$ & 0.27 \\
\hline BMI $\left(\mathrm{kg} / \mathrm{m}^{2}\right)$ & $20.6 \pm 4.6$ & $21.3 \pm 6.7$ & 0.41 \\
\hline $\mathrm{FEV}_{1}(\%$ predicted $)$ & $50.1 \pm 23.2$ & $49.0 \pm 20.5$ & 0.74 \\
\hline $\mathrm{FEV}_{\mathrm{I}} / \mathrm{FVC}(\%)$ & $53.3 \pm 11.5$ & $52.4 \pm 11.3$ & 0.58 \\
\hline SGRQ score $(0-100)$ & $40.3 \pm 20.3$ & $41.7 \pm 21.0$ & 0.65 \\
\hline mMRC dyspnea score (0-4) & $2.0 \pm 1.1$ & $1.9 \pm 1.1$ & 0.68 \\
\hline CAT score $(0-40)$ & $12.4 \pm 7.6$ & $11.7 \pm 6.8$ & 0.52 \\
\hline 6-MWD (meter) & $319.6 \pm 102.8$ & $320.5 \pm 100.9$ & 0.96 \\
\hline \multicolumn{4}{|l|}{ GOLD classification n (\%) } \\
\hline I & $10(12.0)$ & $5(6.2)$ & 0.64 \\
\hline II & $26(33.0)$ & $31(38.8)$ & \\
\hline III & $32(40.0)$ & $29(36.2)$ & \\
\hline IV & $11(13.8)$ & $15(18.8)$ & \\
\hline Missing & $\mathrm{I}(\mathrm{I} .2)$ & $0(0.0)$ & \\
\hline \multicolumn{4}{|l|}{ Inhaled medications n (\%) } \\
\hline LAAC & $\mathrm{I}(\mathrm{I} .2)$ & $\mathrm{I}(\mathrm{I} .2)$ & \\
\hline $\mathrm{ICS}+\mathrm{LABA}$ & $49(61.2)$ & $50(62.5)$ & 0.98 \\
\hline$I C S+L A B A+L A A C$ & $30(37.5)$ & $29(36.2)$ & \\
\hline
\end{tabular}

Note: Data were $\mathrm{n}(\%)$ or mean \pm SD.

Abbreviations: COPD, chronic obstructive pulmonary disease; BMI, body mass index; $\mathrm{FEV}_{1}$ (\% predicted), percentage predicted of forced expiratory volume in the first second; $F E V / F V C$, ratio of forced expiratory volume in the first second to force vital capacity; SGRQ, St George's Respiratory Questionnaire; mMRC, modified Medical Research Council scale; CAT, COPD Assessment Test; 6-MWD, 6-minute walk distance; LAAC, long acting anticholinergics; ICS, inhaled corticosteroids; LABA, long acting beta2-agonists; GOLD, Global Initiative for Chronic Obstructive Lung Disease; SD, standard deviation.

respectively). Functional and impact domains of the northern Thai dialect version showed strong correlation $(r=0.71$ and 0.71 , respectively), whereas those of the Thai version showed moderate correlation only ( $r=0.59$ and 0.53 , respectively) (Table 2).

A

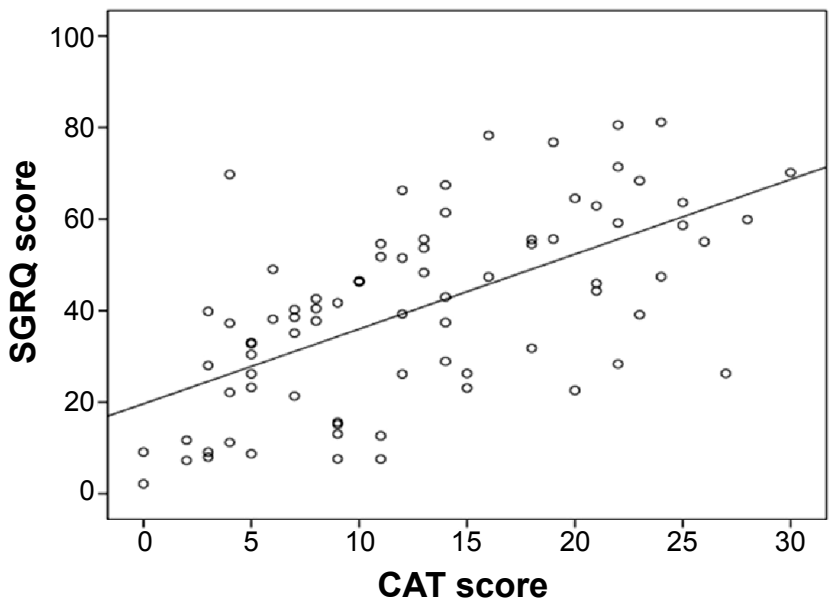

The correlations with $\mathrm{FEV}_{1}$, $\mathrm{mMRC}$, and 6-MWD

Both Thai and northern Thai dialect versions of CAT showed negative correlations with $\mathrm{FEV}_{1}$ and 6-MWD (-0.02 and $-0.19 ;-0.19$ and -0.39 , respectively). However, there were moderate correlations with $\mathrm{mMRC}$ for both versions of CAT ( 0.39 and 0.52 , respectively) (Table 3 ).

\section{Discussion}

This study showed high internal consistency that indicated homogeneity existed among the individual items in the questionnaire. Our study revealed that both Thai and northern Thai dialect CAT questionnaires had good internal consistency with a Cronbach's alpha coefficient of 0.83 and 0.78 , respectively. The good test-retest reliability of them also indicated that they were highly reproducible. These findings implied that the two versions of the CAT questionnaire were reliable for use with Thai COPD patients living in northern Thailand. The correlation with SGRQ was used as a tool to measure the validity of the two Thai versions. Acceptable correlations were found for both versions supporting the validity of them. However, the northern Thai dialect version showed a good level of correlation with SGRQ whereas the Thai version showed only a moderate one. A comparison of each corresponding domain of CAT and those of SGRQ revealed that the symptom domain of the two versions had the same degree of moderate correlation as with SGRQ. However, the remaining two domains (functional and impact) of northern Thai dialect version had good correlations with SGRQ, while the Thai version had only moderate correlations. Therefore, the higher degree of correlations with the functional and impact domains contributed to better correlation with SGRQ for the

B

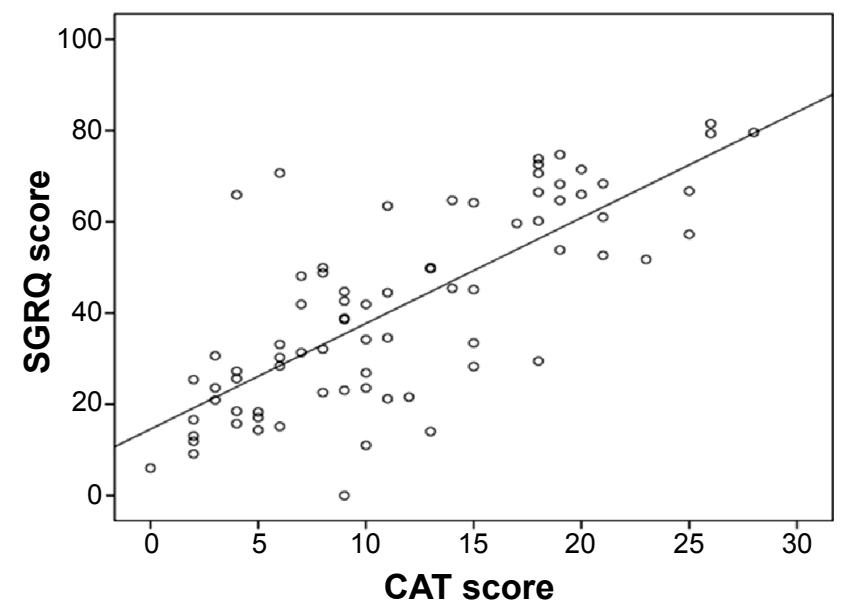

Figure 2 Correlation between SGRQ and CAT scores.

Notes: (A) Thai version $(r=0.60, P<0.001)$ (B) Northern Thai dialect version $(r=0.77, P<0.00 I)$.

Abbreviations: SGRQ, St George's Respiratory Questionnaire; CAT, COPD Assessment Test. 
Table 2 Cross-sectional validity between each domain of CAT and SGRQ at the patients' first visit

\begin{tabular}{|c|c|c|c|c|}
\hline \multirow[t]{2}{*}{ CAT } & \multicolumn{4}{|l|}{ SGRQ } \\
\hline & Symptom & Functional & Impact & Total \\
\hline \multicolumn{5}{|c|}{ Thai version } \\
\hline Symptom & $0.57^{*}$ & $0.28^{*}$ & $0.31 *$ & $0.38^{*}$ \\
\hline Functional & $0.45^{*}$ & $0.59 *$ & $0.51 *$ & $0.60 *$ \\
\hline Impact & $0.37^{*}$ & $0.43^{*}$ & $0.53 *$ & $0.53 *$ \\
\hline Total & $0.54 *$ & $0.5 I^{*}$ & $0.54 *$ & $0.60 *$ \\
\hline \multicolumn{5}{|c|}{ Northern Thai dialect version } \\
\hline Symptom & $0.55^{*}$ & $0.34 *$ & $0.4 I^{*}$ & $0.44 *$ \\
\hline Functional & $0.44 *$ & $0.7 I^{*}$ & $0.68^{*}$ & $0.73 *$ \\
\hline Impact & $0.42 *$ & $0.63 *$ & $0.7 I *$ & $0.7 I^{*}$ \\
\hline Total & $0.56 *$ & $0.69 *$ & $0.74^{*}$ & $0.77^{*}$ \\
\hline
\end{tabular}

Note: *Correlation is significant at the 0.05 level.

Abbreviations: CAT, COPD Assessment Test; SGRQ, St George's Respiratory Questionnaire.

northern Thai dialect version than the Thai version. The result indicates that the northern Thai dialect version is more suitable than the Thai version for evaluating COPD in the study population. The reason is likely to be cultural as most of the patients are elderly and familiar with the northern Thai dialect using it in their daily life while speaking, writing, and reading. Therefore, their comprehension of the items in the northern Thai dialect version could be much better than that in the Thai version. We suggest that the dialect version should be validated for use in COPD patients familiar with their local dialect.

Although CAT is not a diagnostic tool, it can identify the health impairment of COPD patients and is shown to have better correlation with disease progression. ${ }^{15}$ Earlier studies have reported that multiple consequences of COPD have no relationship with airflow limitation and $\mathrm{FEV}_{1}$ cannot reflect the total impairment caused by the disease. These findings

Table 3 Correlations between each domain of CAT and concurrent measures of disease severity

\begin{tabular}{llll}
\hline CAT & \multicolumn{2}{l}{ Disease severity } & \\
\cline { 2 - 4 } & FEV (\% predicted) & mMRC & 6-MWD \\
\hline Thai version & & & \\
Symptom & 0.03 & 0.14 & -0.09 \\
Functional & -0.16 & $0.58^{*}$ & $-0.38^{*}$ \\
Impact & 0.04 & $0.31^{*}$ & -0.12 \\
Total & -0.02 & $0.39^{*}$ & -0.19 \\
Northern Thai dialect version & & \\
Symptom & -0.09 & 0.07 & -0.03 \\
Functional & -0.11 & $0.62^{*}$ & $-0.46^{*}$ \\
Impact & $-0.23^{*}$ & $0.50^{*}$ & $-0.41^{*}$ \\
Total & -0.19 & $0.52^{*}$ & $-0.39^{*}$ \\
\hline
\end{tabular}

Note: *Correlation is significant at the 0.05 level.

Abbreviations: CAT, COPD Assessment Test; FEV (\% predicted), percentage predicted of forced expiratory volume in the first second; mMRC, modified Medical Research Council scale; 6-MWD, 6-minute walk distance. confirm that $\mathrm{FEV}_{1}$ is a relatively poor correlate of symptoms such as breathlessness and health status of COPD patients. ${ }^{16}$ In contrary, mMRC functional dyspnea with moderate correlations has proven to be a better parameter in predicting outcomes in patients with COPD as in earlier studies ${ }^{1}$ and should be recommended in the routine evaluation of these patients. The 6-MWD, a parameter that provides reproducible data in the assessment of functional status, ${ }^{17}$ has contradictory results in this study as it shows poor correlation for the Thai version and moderate correlation for the northern Thai dialect version. This study has a few limitations. Firstly, the results of our findings may not be generalized for all the GOLD severity stages and age groups because most of our subjects were in GOLD stages II-III and elderly. Secondly, most of our findings are based on data from a single center only and might not be reliably extrapolated to the entire northern region. However, it is well-known that CAT has very similar discriminative properties compared to the more complex SGRQ, proving that it could become a standard procedure to measure the impact of COPD on a patient's health. ${ }^{7}$ Although the CAT questionnaire showed very similar property compared to the more complex SGRQ, it could not be recommended to be used in making important decisions about individuals. ${ }^{18}$ However, CAT could play a supporting role in supplementing information obtained from lung function measurement and assessment of exacerbation risk. ${ }^{7}$

\section{Conclusion}

The two Thai-versions of CAT were proved to be reliable and valid tools for assessing the quality of life in COPD patients. The northern Thai dialect version is found to be more suitable than the Thai dialect version for evaluating COPD patients living in the northern part of Thailand. The result of this study raises the awareness of the influence of regional dialect on the validity of CAT for ensuring clear communication with COPD patients in the same country.

\section{Acknowledgments}

The authors wish to thank the patients who kindly took part in this study and to acknowledge the staff members of the Division of Pulmonary, Critical Care and Allergy, Department of Internal Medicine, Faculty of Medicine, Chiang Mai University for their contribution to this trial. The COPD Assessment Test is a trademark of GlaxoSmithKline group of companies.

\section{Author contributions}

$\mathrm{CP}$ developed the study design and carried out the acquisition and interpretation of data, statistical analysis, manuscript 
preparation, and critical revision of intellectual contents. The other authors contributed to the acquisition and interpretation of data, revised the article for important intellectual contents, and obtained the final approval of the version to be published.

\section{Disclosure}

The authors report no conflicts of interest in this work.

\section{References}

1. Celli BR, MacNee W; ATS/ERS Task Force. Standards for the diagnosis and treatment of patients with COPD: a summary of the ATS/ERS position paper. Eur Respir J. 2004;23:932-946.

2. Murray CJ, Lopez AD. Mortality by cause for eight regions of the world: Global Burden of Disease Study. Lancet. 1997;349:1269-1276.

3. Murray CJ, Lopez AD. Global mortality, disability, and the contribution of risk factors: Global Burden of Disease Study. Lancet. 1997;349: $1436-1442$

4. Murray CJ, Lopez AD. Alternative projections of mortality and disability by cause 1990-2020: Global Burden of Disease Study. Lancet. 1997; 349:1498-1504.

5. Jones PW, Quirk FH, Baveystock CM, Littlejohns P. A self-complete measure of health status for chronic airflow limitation: the St George's Respiratory Questionnaire. Am Rev Respir Dis. 1992;145:1321-1327.

6. Guyatt GH, Berman LB, Townsend M, Pugsley SO, Chambers LW. A measure of quality of life for clinical trials in chronic lung disease. Thorax. 1987;42:773-778.

7. Jones PW, Harding G, Berry P, Wiklund I, Chen WH, Kline LN. Development and first validation of the COPD Assessment Test. Eur Respir J. 2009;34:648-654.
8. Global Initiative for Chronic Obstructive Lung Disease (GOLD). Global Strategy for the Diagnosis, Management and Prevention of COPD; 2014. Available from: http://www.goldcopd.org. Accessed August 1, 2014.

9. Jones PW, Quirk FH, Baveystock CM. The St George's Respiratory Questionnaire. Respir Med. 1991;85(suppl B):25-31.

10. Bestall JC, Paul EA, Garrod R, Garnham R, Jones PW, Wedzicha JA. Usefulness of the Medical Research Council (MRC) dyspnoea scale as a measure of disability in patients with chronic obstructive pulmonary disease. Thorax. 1999;54:581-586.

11. Knudson RJ, Lebowitz MD, Holberg CJ, Burrows B. Changes in the normal maximal expiratory flow-volume curve with growth and aging. Am Rev Respir Dis. 1983;127(6):725-734.

12. ATS Committee on Proficiency Standards for Clinical Pulmonary Function Laboratories. ATS statement: guidelines for the six-minute walk test. Am J Respir Crit Care Med. 2002;166:111-117.

13. Cronbach LJ. Coefficient alpha and the internal structure of tests. Psychometrika. 1951;16:297-334.

14. Stallberg B, Nokela M, Ehrs PO, Hjemdal P, Jonsson EW. Validation of the clinical COPD Questionnaire (CCQ) in primary care. Health Qual Life Outcomes. 2009;7:26.

15. Jones PW, Brusselle G, Dal Negro RW, et al. Properties of the COPD assessment test in a cross-sectional European study. Eur Respir J. 2011; 38:29-35.

16. Jones $\mathrm{P}$, Miravitles $\mathrm{M}$, van der Molen $\mathrm{T}$, Kulich K. Beyond $\mathrm{FEV}_{1}$ in COPD: a review of patient-reported outcomes and their measurement. Int J Chron Obstruct Pulmon Dis. 2012;7:697-709.

17. Hajiro T, Nishimura K, Tsukino M, Ikada A, Koyama H, Izumi T. Comparison of discriminative properties among disease-specific questionnaires for measuring health-related quality of life in patients with chronic obstructive pulmonary disease. Am J Respir Crit Care Med. 1998; 157(3 pt 1):785-790.

18. Nunnally JC, Bernstein IH. Psychometric Theory. 3rd ed. New York: McGraw-Hill; 1994. 


\section{Supplementary materials}

Table SI Thai version

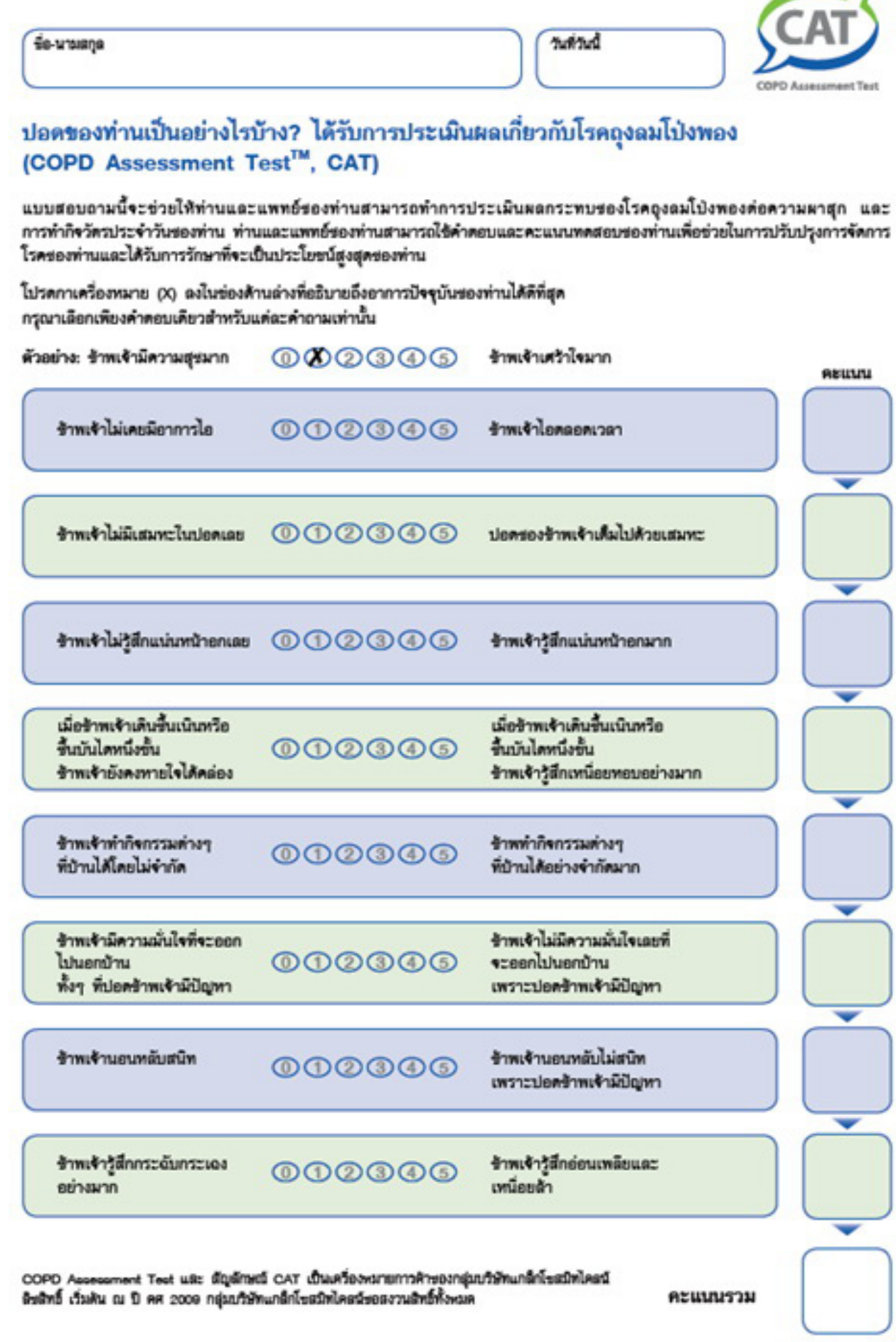


Table S2 Northern Thai dialect version

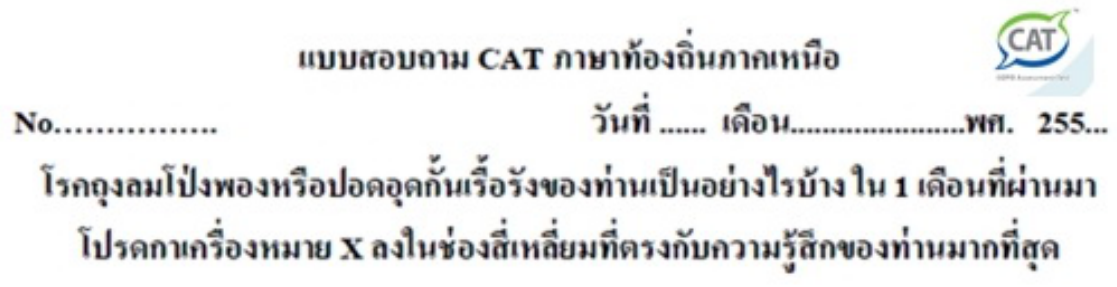

\begin{tabular}{|c|c|c|c|c|c|c|c|}
\hline การประเมินอาการของโรด & 0 & 1 & 2 & 3 & 4 & 5 & การประเมินอาการของโรด \\
\hline เซาบ่ไอเลย & 0 & 1 & 2 & 3 & 4 & 5 & เซาไอวันค่ำคืนยุ่ง \\
\hline ปอดเซาบ่มีขี่เต้อเลย & 0 & 1 & 2 & 3 & 4 & 5 & ปอดเซามีขี้เต้อเด้มไปหมด \\
\hline เซาบ่สู้สีกกั้ดอกเลย & 0 & 1 & 2 & 3 & 4 & 5 & เซายู้สีกกั้ดอกนักขนาด \\
\hline $\begin{array}{l}\text { เซาบ่ยู้สึกอิดเลยเมื่อเดี่ยวขึ้นหลิ่งกา } \\
\text { ว่าเตียวขึ้นข้้นไดหนึ่งจั้น }\end{array}$ & 0 & 1 & 2 & 3 & 4 & 5 & $\begin{array}{l}\text { เซายู้สึกอิดนักเมื่อเที่ยวขึ้นหลิ่ง } \\
\text { กาว่าเตียวขึ้นข้้นไดหนึ่งจั้น }\end{array}$ \\
\hline $\begin{array}{l}\text { เซาบ่ถูกจำกัดในก๋าน เยี้ยะก๋าน } \\
\text { เยี้ยะงานในบ้าน }\end{array}$ & 0 & 1 & 2 & 3 & 4 & 5 & $\begin{array}{l}\text { เซาถูกจำกัดในก๋านเยี้ยะก๋าน เอียะงาน } \\
\text { ในบ้านเกือบหมด }\end{array}$ \\
\hline $\begin{array}{l}\text { เซายู้สึกมั่นใจตื้จะออกไปนอกบ้าน } \\
\text { ทั้งตื้ปอดเซามีปั่นหา }\end{array}$ & 0 & 1 & 2 & 3 & 4 & 5 & $\begin{array}{l}\text { เซายู้สีกบ่มั่นใจตื้จะออกไปนอกบ้าน } \\
\text { เพราะปอดเซามีปั่นหา }\end{array}$ \\
\hline เซานอนหลับจัาดดี & 0 & 1 & 2 & 3 & 4 & 5 & เซานอนหลับบ่ดีเพราะปอดเซามีปีญหา \\
\hline เซาฮู้สึกมีเยี่ยวมีแยงนัก & 0 & 1 & 2 & 3 & 4 & 5 & เซายู้สึกบ่มีเซี่ยวแยงเลย \\
\hline
\end{tabular}

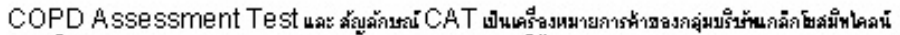

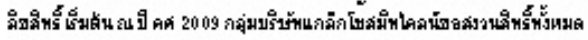

คะแหนรวม

\section{Publish your work in this journal}

The International Journal of COPD is an international, peer-reviewed journal of therapeutics and pharmacology focusing on concise rapid reporting of clinical studies and reviews in COPD. Special focus is given to the pathophysiological processes underlying the disease, intervention programs, patient focused education, and self management protocols

This journal is indexed on PubMed Central, MedLine and CAS. The manuscript management system is completely online and includes a very quick and fair peer-review system, which is all easy to use. Visit http://www.dovepress.com/testimonials.php to read real quotes from published authors. 